\title{
Teacher Professional Socialisation: Objective Determinants
}

\author{
Michaela Píšová \\ Masaryk University in Brno, Faculty of Education
}

\begin{abstract}
Entry into teaching is generally recognised as a crucial phase in the professional life of a teacher. The initial years at school can be a critical part of a teacher's career having long-term implications for teacher effectiveness, job satisfaction and also career length. The problem of a high drop-out rate of novice teachers has gradually become a global issue. Therefore, teacher professional socialisation as a specific field within a larger body of research into occupational socialisation has received increased attention in the last decades. The paper presents a brief overview of teacher socialisation research paradigms within which both the anticipatory socialisation (pre-service) and the workplace (organisational) socalisation are investigated. Further on, the focus is specifically on the latter and on the factors that determine the processes of workplace socialisation of novice teachers. While recognising the significance of subjective determinants, we aim to survey mainly the objective ones in this article. Three layers of social context are addressed: interactive (pupils and classrooms), institutional (school culture, staff, and leadership) and cultural (local social community as well as broader economic, political and cultural environment).
\end{abstract}

Keywords: teacher socialisation, novice teacher, objective determinants of novice teacher socialisation, interactive, institutional and cultural levels of analysis

\section{Introduction}

Entry into teaching is generally recognised as a crucial phase in the professional life of a teacher. The initial years at school can be a critical part of a teacher's career, having long-term implications for job satisfaction and career length. It is the period during which professional identity is sought and formed (for a review see Cherubini, 2009). As such it has been in the centre of attention of researchers worldwide for decades (e.g. Waller, 1932). Within the plethora of studies two main orientations may be distinguished: a socio-pedagogical orientation, i.e. research focusing on teachers' career development (career paths, professional lives of teachers), and research in the development of teacher effectiveness in a school classroom (or, in the contemporary discourse, the development of professional competence of teachers) rooted mainly in didactics, pedagogy and cognitive psychology. It is the former perspective this text aims to address acknowledging their mutual interconnection at the same time.

Since the late 1950s, one of the main reasons for increased attention to the initial phase of teachers' career has been, particularly in Great Britain and the United States, the joint problem of teacher shortages and the high drop-out rate of young 
68 teachers (Battersby, 1981, p. 25). The concern for teacher retention and attrition rates has gradually become a global issue as evidenced by numerous contemporary studies conducted all over the world: retention was investigated in connection with teacher morale in Great Britain (Rhodes et al., 2004); with satisfaction and motivation of teachers in Australia, England and New Zealand (Dinham \& Scott, 1998); with satisfaction in the USA and China (Ouyang \& Paprock, 2006) as well as Taiwan (Fwu \& Wang, 2002), etc. An international overview of research in this area was provided by Cooper \& Alvarado (2006). The data from the last decades in the USA indicate that it is especially novice teachers who leave the profession within a few years. Darling-Hammond (2000) noted that the rate of attrition among teachers in their first two years of teaching is at least double the average for teachers overall. According to Perez et al. (1997), 30\% of beginning teachers leave teaching during that time; Ingersoll (2003) stated that the number goes up to $50 \%$ within five years of teaching. Such an attrition rate represents a serious economic loss (in Texas the State Board of Education carried out a study to assess the fiscal cost of a teacher 'lost' during the induction years: the estimate after considering the investment in teacher preparation, recruitment, professional development and support went up to $\$ 50,000)$. What can hardly be estimated in dollars - and what is perhaps even more important - is the effect that rapid turnover of teachers has on the quality of teaching and thus the quality of pupils' learning.

Data by the Czech School Inspectorate are available for the context of the Czech educational system but we are not aware of any research based data concerning novice teachers' dropout and its causes. It is certain, however, that the situation does not significantly differ from the rest of the world. The shortage of qualified teachers in some of the school subjects (e.g. foreign languages) has already become notorious ${ }^{1}$.

The above data indicate that it is vital to gain a deeper insight into the processes of professional initiation at the workplace, into teacher socialisation. Socialisation is a concept used in sociology, social psychology, education, anthropology and other disciplines. The definitions vary in different theories of socialisation; e.g. Zeichner and Gore (1990, p. 329) in their seminal paper build on a broader Danzingers' (1971) view of socialisation research as "that field of scholarship which seeks to understand the process whereby the individual becomes a participating member of the society of teachers".

According to the Annual Report 2010-2011 (the last one displayed on the Czech School Inspectorate web pages; http://www.csicr.cz/getattachment/e1b96137-2102-4a87-8cae-7384d9dba60c, 2012, p. 80) $70.9 \%$ of teachers of English met the qualification criteria, and only $28.2 \%$ met the specialisation criteria at primary and lower secondary levels. As regards teachers of German, the situation is slightly better $(75.1 \%$ and $53.2 \%)$, teachers of other languages are not mentioned. Attrition rates are not provided either. 


\section{Approaches to teacher socialisation research}

Teacher socialisation is a specific field of investigation developing within a larger body of research into occupational socialisation. The term socialisation has been deployed in connection with the teaching profession for decades; Danziger (1971) traced the current usage of the term to Waller (1932), Park (1939) and Sutherland and Woodward (1937). Over time, teacher socialisation research has adopted various theoretical stances in line with the paradigms of occupational research. Zeichner and Gore (1990, p. 329) highlighted three primary paradigms in the study of teacher socialisation namely a functionalist, interpretive and critical approaches.

The functionalist approach enthused by structural functionalism (Merton, 1968) is perhaps the most commonly applied one. It gives social structures analytical priority over individuals whose behaviour is conceptualised as generally determined by the social context in which they find themselves. In that context, professional socialisation is viewed as "the process by which persons acquire the knowledge, skills and disposition that makes them more or less effective members of society" (Weidman, Twale, \& Stein, 2001, p. 27). The functionalist stance tends to be realistic, positivist, determinist and nomothetic (Burrell \& Morgan, 1979, p. 26). Reacting against functionalism, the interpretive approach to socialisation focuses on human agency. It seeks explanation "within the realm of individual consciousness and subjectivity, within the frame of reference of the participant as opposed to the observer of action" (Burrell \& Morgan, 1979, p. 28). In this view, professional socialisation is not a static process in which new students only receive the impression of the organization. It is a dynamic process in which the new student brings experiences, values and ideas into the organization. The paradigm is characterised as nominalist, antipositivist, voluntarist and ideographic (ibid., p. 28). Zeichner and Gore (1990, p. 332) pointed out that though the functionalist and interpretive approaches are fundamentally different, they share a value-neutral stance, their concern being either for explanation (functionalist perspective) or for understanding (interpretive view). Unlike that, the critical approach aims at social transformation, at increasing equality, freedom and justice, etc. (Carr \& Kemmis, 1986, p. 156). Reality is viewed as socially created and sustained, the basis of the critical approach is reflexivity. (Zeichner \& Gore, 1990).

\section{Stages of socialisation}

Teacher socialisation is often described as a staged process. Zeichner and Gore (1990, p. 336-354) reviewed influences on teacher socialisation in the following three stages: (a) prior to formal teacher education, (b) during pre-service teacher education, and (c) during the in-service years of teaching. Similarly, Staton and Hunt (1992) created a chronological model of teacher socialisation which includes three categories: biography, pre-service experience and in-service experience. The first two phases that 
70 occur before and during the professional education period are sometimes labeled anticipatory socialisation (Olesen \& Whittaker, 1970). It is often argued that the beliefs and stereotypes related to the role and behaviour of teachers created during anticipatory socialisation become a perceptual and cognitive filter and determine teacher post-entry socialisation (for a survey of literature see Cherubini, 2009). Furthermore, formal and informal socialisation are often distinguished in the main socialisation processes, i.e. in acculturation and in professional and organizational socialisation.

A non-linear model of teacher socialisation was offered in a much cited monograph by Weidman, Twale and Stein (2001); the model was developed with specific focus on the second phase, on graduate student teachers socialisation during their study at tertiary educational institutions. In Figure 1 an adaptation of this model is presented which attempts to shift the attention to the last stage of teacher socialisation, to entrants to the profession (novices after their entry to their workplaces, to schools). The model places teacher socialisation processes, i.e. professional learning linked to interaction and integration, within a complex environment which includes specific factors determining these processes.

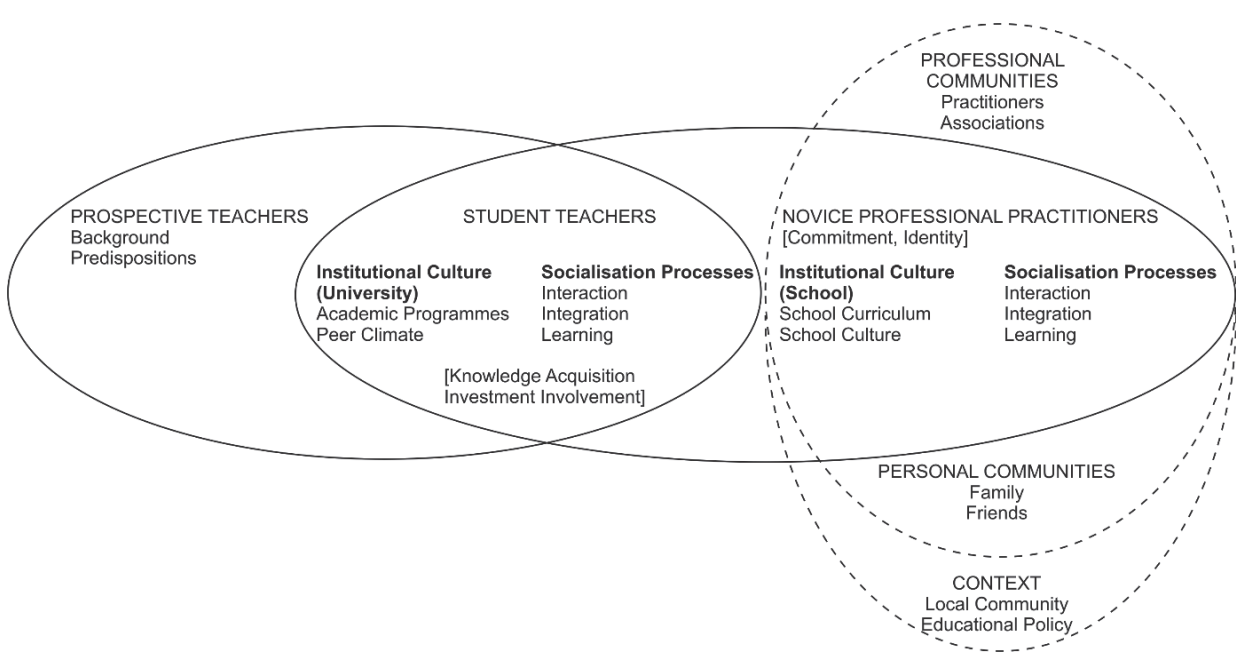

Figure 1 Model of teacher professionalisation (adapted after Weidman, Twale, \& Stein, 2001)

Further on, the factors influencing teacher in-service professionalisation stage, i.e. "the classrooms", institutional culture and a broader context, will be dealt with in more detail.

\section{In-service stage of teacher socialisation}

Reviews of research into the initial phase of teacher career path (Battersby, 1981; Zeichner \& Gore, 1990; Cherubini, 2009; Keller-Schneider, \& Hericks, 2011; in the 
Czech context Šimoník, 1995; Průcha, 2002, p. 23-29; Pišová, 1999, 2005; and others) bring up various aspects of teacher socialisation. Back in 1981, Battersby (1981, p. 26) in his review as well as others later on noticed that despite the differences resulting from broader cultural, historical, political, socio-economic and contextual determinants, uniform global trends in teacher socialisation processes may be identified.

The state of the art in the field offers the following characteristics of novice teacher life phase: Huberman et al. (1993) in their extensive study of teachers' professional life cycles concluded that teachers' early careers are marked by phases of exploration and stabilisation. The new teacher, according to these authors, is initially involved in a personal investigation of the dynamics of their role in the context of professional culture and then explores and experiments with these suppositions. If this exploration is positive, his/her professional self begins to stabilise by approaching the various technicalities that the role entails on a more systematic level. "The development of the profession is, therefore, a process rather than a successive series of punctual events [...], in short, discontinuities" (Huberman et al., 1993, p. 4).

Drawing on these ideas of Huberman and on the ideas of Hansen (1995) that teacher development "happens" in the context of a vocation, Day and Gu (2010, p. 44-45) emphasised the notion of teachers' professional life (rather than career) in order to encapsulate also the impact of personal, emotional and organisational factors. In other words, how teachers differ within and along their professional life phases needs to be discussed on the basis of policy, organisational and classroom settings, and how these interact with events from teachers' personal lives. The perception and reactions to external influences, however, are probably largely shaped by the first phase of a teacher's professional life when his/her professional identity is sought and formed.

Even within the novice life phase, teachers were repeatedly described as proceeding through distinct sub-phases of professional development (Lortie, 1975; Lacey, 1977; etc.). For illustration, a model by Furlong and Maynard (1995, p. 68-99) includes five sub-phases: (1) initial idealism; (2) survival; (3) recognizing difficulties; (4) hitting the plateau; (5) moving on. The pace novices take up to go through differs in individuals and their environments. Therefore, Ball and Goodson (1985, p. 11) described the concept of professional career and its beginning as "socially constructed and individually perceived".

As regards the factors that may play the key role in novice teachers' professional socialisation in the contemporary Czech context, we find it useful to distinguish along with Pařizek (1994, p. 61-67) between subjective and objective determinants of socialisation processes. While recognizing the significance of subjective (or internal) determinants that include novice teacher's personality traits, reflective potential, coping strategies, commitment, professional knowledge and beliefs, and the value system of a teacher, this analysis will focus predominantly on the objective determinants, such as the organisational setting, i.e. the school and its culture (including the pupils, staff and leadership), the broader social community in which the teacher operates (including the parents), and the profes- 
72 sional, economic, political and cultural environment. The socialising influence of the workplace is captured in Pollard's (1982) conceptual model describing three levels of social contextualisation. Pollard (1982) believed that teachers respond by their actions to this immediate context in an active and creative way and, furthermore, that it is this context that shapes their perception of the wider structure of the community, society and the state. He identified three levels of environmental influences: interactive (pupils and classrooms), institutional (school culture, staff and leadership) and cultural (local social community as well as broader economic, political and cultural environment).

\subsection{Specific aspects of entry}

A number of socialisation problems common to novice teachers globally may be ascribed to the specific aspects of entry to the profession which are relevant for the first two levels of Pollard's model. Lortie (1975, p. 59) formulated it in a pertinent way noting that "one of the striking features of teaching is the abruptness with which full responsibility is assumed". Unlike in other professions, novices are expected to carry out the same professional duties as veteran teachers immediately. No time (and often limited support) are provided for them to adapt to their new social roles, to the complexity of professional tasks, the pressure being often exacerbated by a radical change in their personal lives.

Another specific aspect of entry to teaching is, again in Lortie's words (1975, p. 61-62), the long "apprenticeship of observation". Individual preconceptions created through this process may play a key role and make the induction experience stressful, the number and complexity of demands sometimes leading to a so-called transition shock (cf. large-scale research at Konstanz University in Germany). At its worst, the transition shock may contribute to burnout: the stress is identified as overwhelming and a contributing factor of new teachers' depleting energy levels and emotional capacities.

Burnout has been observed relatively often with newly qualified teachers (Zehm \& Kottler, 1993, p. 87). A generally stressful character of the teaching profession is universally recognised. For newly qualified teachers, the specifics of entry coincide with general causes of occupational stress which makes them especially vulnerable. Nathan (in Tolley et al., 1996, p. 41) identified the following specific stressors of novice teachers as: "pressure of work including the amount of time which has to be spent on lesson preparation", "lack of confidence and low self-esteem resulting from anxiety about getting things wrong, and overestimating the importance of perceived failures in the classroom, setting unrealistic objectives which cannot be achieved, being required [...] to cope with a multiplicity of tasks in addition to teaching", "difficulty in gaining access to information, equipment and resources" and, furthermore, personal issues linked to novice's new life phase. Implicit in this list are external conditions which may either exacerbate the perceived level of pressure or moderate it on the other hand. 


\subsection{Socialising influence of classrooms: interactive level of analysis}

Zeichner and Gore (1990, p. 342) pointed out that the emphasis on socialising influence of pupils and classrooms on teachers is supported both on logical grounds and by empirical evidence. The 'logical' explanations usually link the importance of pupils and classrooms to a typical isolation of teachers from their colleagues as well as to the 'invisible' nature of professional learning processes (Doyle, 1979). These arguments are supported by a substantial number of empirical studies; Cherubini (2009, p. 86-87) provided us with a review of studies dated since the publication of Veenman's (1984) important international study of the main concerns about beginning teachers' socialisation. Among the five predominant concerns identified by Veenman (1984) four relate to pupils: classroom discipline, pupil motivation, teacher - pupil relationships and assessing pupils' work. Nowadays, novice teachers are confronted with a new generation of learners. Discipline problems, pupils'/ students' attitude towards learning and lack of motivation are recognised as causes of occupational stress (Hennig \& Keller, 1996, p. 9-10, for the Czech context e.g. Bendl, 2011). Though they are 'evergreens' in teachers discourse, currently they have taken up a new shape and unexpected representations, thus posing a challenge to the expectations of novices.

Moreover, Doyle (1979) argued that pupil effects are just one facet of the larger matter of the effects of classrooms on teachers. He emphasised the role of the ecology of the classroom in teacher socialisation, namely factors related to the material conditions and social organisation of the classroom (teacher-pupil ratios, lack of resources, limited time and financial problems).

\subsection{Socialising influence of school and its culture: institutional level of analysis}

Occupational culture and institutional culture ${ }^{2}$ are complex phenomena. An extensive body of literature documents "an escalating interest in the socio-psychological conditions and circumstances of teachers' work" (Little \& McLaughlin, 1993, p. 1; for the Czech context e.g. Pol, 2013). For the purpose of this discussion we build on the perception of school culture as "the distinctive blend of norms, values and accepted modes of professional practice, both formal and informal, that prevails among colleagues" (Bryk \& Driscoll, 1988, p. 253). All schools are positioned within their own histories that exist before teachers enter them. For new teachers it means that they must engage immediately in discourse and behaviour/s already established (Scherff, 2008, p. 1319). Weiss (1999) found in her analysis of a nationwide sample of beginning teachers in the USA that their views of the social organization of their

2 For conceptual discussion and definitions of the terms culture, climate, ethos, etc. see Mareš (2003). 
74 schools (including leadership and culture) were the variables most closely associated with morale, career choice, commitment and planned retention. Our study of novices' induction experience carried out at about the same time in the Czech Republic (Píšová, 1999) generated similar results - school culture was identified as the main cause of novice teachers' concern, the reason why three quarters of respondents in the research have decided or considered leaving the profession.

Lortie (1975, p. 56) believed that in teaching the occupational culture in general is characterised by privatism and survival strategies, though such characteristics, which turn induction into 'sink or swim in private', are not necessarily predominant in every single school. Over the past decades a campaign for cooperative schools was very strong based on the belief that the ethos of collegiality, supportive criticism and systematic reflection on practice would encourage similar dispositions in teachers and help create communities of practice. The 'cooperative rhetorics' has not been fully unanimous though, as e.g. Little and McLaughlin (1993, p. 2) pointed out. According to them "the initial enthusiasm about the benefits of collegiality has been followed by increasing scepticism" in the light of growing research on staffroom culture and the evidence provided by its results.

As school culture/climate has also received much attention in the Czech Republic (various studies by Mareš, Prokop, Pol and his colleagues, Grecmanová, Chráska, Tomanová and Holoušová, Ježek, etc.), we restrict the focus here on the aspects/ dimensions that may be of special importance in novice teachers' socialisation processes.

An important element of institutional culture is the school hierarchy, mainly the leadership, its style and the management structure. According to West-Burnham's (1995) analysis of leadership tasks, headmasters are responsible for formulating and communicating a vision for the school, thus creating a positive atmosphere. Moreover, novice teachers acknowledge the head's role as a leading professional, expecting at the same time that instructional leadership will respect a certain degree of teacher autonomy (Ball \& Goodson, 1985, p. 15). Lortie (1975, p. 200) pointed out that "the acceptance of the principal's authority is coupled with definite ideas on how the authority should be deployed". Generally, democratic leadership based on collegial decision making is considered to be the most effective according to current theories of educational management. Research results, unfortunately, indicate that teachers' participation in making decisions concerning whole school policies is usually relatively low (e.g. Pol \& Rabušicová, 1997, p. 95-100 for Czech schools). In case of novice teachers, moreover, truly open relationships with senior management and participation in decision making are constrained by the perception of the headteacher's dual role as an advisor and an assessor. Generally speaking, the success of a novice teacher's socialisation is supposed to be facilitated by an open door policy with "leadership visible presence" (West-Burnham, 1995, p. 27) and “leader approachability” (Humphreys, 1993, p. 70).

Most studies point to staff relationships as the key factor of success or failure of novice teachers' socialisation processes; e.g. Putz's extensive synthesis of literature 
in 1992 highlighted relationship among colleagues and staff as one of the four main concerns in novices' acclimatisation into school culture. Beginning teachers' interactions with colleagues are described as a complex and sensitive series of exchanges, with emphasis on new teachers' ability to uphold a cohesive relationship with the school community (Cherubini, 2009, p. 87). Such an active engagement of a novice is expected to be facilitated by the collegial culture with high frequency of interaction, inclusive collegial grouping and shared value orientation (Little \& McLaughlin, 1993, p. 6). A fundamental prerequisite of cooperation is mutual trust (Hargreaves, 2002, p. 393-407) which permits for the highest level of cooperation - joint work such as, for example, team teaching, mutual observations and joint planning (Pol \& Lazarová, 1999, p. 15).

Unfortunately, research into school culture seems to indicate that in spite of social changes and theoretical development in this area, relationships among colleagues have not changed in many schools since Lortie's analysis (1975). The reasons are often ascribed to the specifics of teachers' work: isolation as a feature of classroom performance, lack of feedback (or feedback from learners rather than from colleagues). These factors may drive a novice into defensive behaviour patterns, especially at schools with general 'culture of non-interference' (Huberman et al., 1993 , p. 29) where 'deceptive discourse', i.e. social small talk rather than professional debate, prevails (Eraut, 2002, p. 373). Generally speaking, a cooperative school culture seems to be better suited to novice teachers' needs. But, as Little (1990, p. 174-175) warned, even highly collegial schools do not automatically represent an optimal environment for a newcomer; she observed that collegial teams have their standard of productivity, dynamic pace, accumulated knowledge base and shared language which may cause assimilation problems for a novice and, at the same time, his/her presence may endanger effective functioning of the team.

More generally it may be stated that during the initial phase of socialisation into institutional culture a young teacher discovers the rules of conduct, hidden agendas and micro-political power structures. Gender, age and even physical facilities such as the presence or absence of a staffroom (Píšová, 1999) may play an important role in establishing relationships with colleagues. Research proves that the quality of interactions between novice teachers and their more experienced colleagues impacts their decision to remain in the profession or not (e.g. Weiss, 1999).

It has been repeatedly noted that one way to ease the assimilation of novices and reduce the attrition rate is through supportive induction. Mentoring programmes were paid most attention to within the various models of professional induction and supportive measures (Darling-Hammond, 2003; Rippon \& Martin, 2006; Píšová, Duschinská et al., 2011 for the Czech context). Mentoring as personal long-term support for novices and as facilitation of professional learning processes has become one of the leading forms of teacher induction (and, indeed, of school-based teacher education) in a number of countries in Europe and overseas (Ingersoll \& Smith, 2004). As such, it has been thoroughly researched (for more details see Píšová et al., 2011). Unfortunately, in the Czech Republic mentoring as well as any other job-embedded 
76 support schemes are still solely in the hands of individual schools at present. Novice teachers usually open up informal vertical relationships first (e.g. within their subject committees; Ball \& Goodson, 1985, p. 9) and often rely heavily on support from and through the generation cliques or on informal friendships; they find sympathy and someone they may trust there but hardly ever expert advice. Effective mentoring, however, should not only stand as the source of support, the other key dimension of mentoring to be put in balance here is challenge (Píšová et al., 2011, p. 50).

Mentors also often become the main sources of professional affirmation. There are certainly not many extrinsic rewards in (not only) novice teachers' work: "the tradition of teaching makes people who seek money, prestige, or power somewhat suspect" (Lortie, 1975, p. 102). However, intrinsic or "psychic rewards", as Lortie calls them, are an essential prerequisite for positive self-esteem which is recognised as an important variable in successful induction. Taking into account the frequent lack of clear criteria for a functioning teacher appraisal system, informal signals of affirmation from others, i.e. mentors, colleagues and leaders, often become the main "psychic rewards" for a novice teacher. Unfortunately, as Humphreys (1993, p. 71) noted, "recognition, respect, valuing, affirming, encouragement, praise are not regular features of staff/staff or leader/staff interactions."

\subsection{Socialising influence of local community and social context: cultural level of analysis}

Schools do not operate in a vacuum, their immediate environment exerts strong influence on them, on their culture. Social changes all over the world are reflected in an increase in the responsibility of the school linked to the deteriorating role of the family, to the 'impossible' demands and expectations imposed on schools by society (to prevent and/or eliminate emerging negative social issues such as drug abuse, xenophobia, etc.). Such demands go hand in hand with critical attitude of parents towards school and further decrease the status and prestige of the occupation which constantly forces the teachers on to the defensive. Scherff's study (2008, p. 1329) may serve as an example: her novice teacher was confronted with the situation when

the power rested not with classroom teachers, but with students (and their parents) who, in turn, influenced how administrators operated. Appeasing parents came at the expense of teacher control, decision-making, and professionalism. At [...] / the name of the school/, reputation was key, and as long as the school looked good in the eyes of the public, things were okay.

The example serves as illustration of ways in which the neo-liberal trend in education (Štech, 2007) may materialise and directly affect the school culture, thus influencing novices' socialisation processes. At its worst, in combination with a novice's low professional self-esteem and other stressors typical of professional initiation, it may contribute to the decision to abandon the profession.

The impact of neo-liberal era on education mentioned above and illustrated in one example is obviously overarching - Štech (2007, p. 328-330) spoke about a dra- 
matic turn in the history of school education. His enumeration of the basic postulates of educational neo-liberalism such as individualisation, de-regulation, i.e. free and responsible choice, utilitarian conception of education and the perception of education as a market commodity, has clear implications for the teaching profession - and the more so for a self-conscious novice. Research in the Western countries repeatedly pinpointed the effects of neo-liberal reforms on school culture and on teacher professionalism: erosion of value systems, weakening of school autonomy, culture of competitiveness, domination of accountability, etc. The shift is well captured by Sachs' (1999, page not provided) distinction of democratic professionalism and managerial professionalism of teachers, the latter being characterised as "an ideology with two distinct claims: that efficient management can solve any problem; and that practices which are appropriate for the conduct of private sector enterprises can also be applied to the public sector".

Research suggests that a school culture which values external measures as representative of student learning is marked by a distinct identity that translates into the reinforcement of certain behaviours over others (Darling-Hammond, 1997). With a pervasive concentration on external accountability the novice teachers' anxiety is further strengthened by the burden of being pressured to assimilate their practice and conceptualise their paradigms to the school's occupational purposes (Cherubini, 2009). To provide a counterbalance, an interesting finding by Huberman et al. (1993, p. 34-36) may be quoted: after comparing the results of his research with the outcomes of other studies he concluded that in the periods of abrupt or intense educational change, during a reform or innovation, higher levels of teacher cooperation may be observed; even rigid schools and fierce opponents of cooperation within them consider joint efforts to solve new problems legitimate.

\section{Conclusion}

The paper focused on the initial phase of the professional lives of teachers. The impetus to deal with this issue comes from the recognition of the immense importance of professional entry not only for teacher retention, i.e. for a definite career choice of an individual, but also for the the emerging professional identity of a new teacher. Professional socialisation is perceived as more than just acquiring the skills and knowledge necessary to perform a role, it also includes understanding and internalising the values and norms that are fundamental to the essence of the profession. Though there is a growing body of research providing deeper insight into teacher socialisation processes, its results especially from the studies conducted in the English speaking countries indicate that novices' induction experience brings about a lot of the initial concerns which have been documented about beginning teachers for over 35 years. It is worth noting, that such conclusion may be formulated despite the educational reforms in Canada, the USA, the United Kingdom and Australia over the last three decades (Cherubini, 2009, p. 83). 
The focus on objective determinants of novice teacher socialisation we have opted for in this paper is linked to the current educational context in the Czech Republic. Discussions about teacher career system which would encompass a systemic attention to novice teacher induction have been going on for almost two decades. It is a must to take into consideration the lessons learned from research in designing such a systemic support scheme aimed at increasing the quality of education through its key agents, the teachers.

\section{References}

Ball, S. J., \& Goodson, I. F. (Eds.). (1985). Teachers' lives and careers. London: The Falmer Press.

Battersby, D. (1981). Beginning teachers: a review of research. Australian Journal of Teacher Education, 6(2), 25-39.

Bendl, S. (2011). Kázeňské problémy ve škole. Praha: Triton.

Bryk, A., \& Driscoll, M. E. (1988). The high school as community: Contextual influences and consequences for students and teachers. Madison, WE: National Center on Effective Secondary Schools.

Burrell, G., \& Morgan, G. (1979). Sociological paradigms and organizational analysis. London: Heinemann.

Carr, W., \& Kemmis, S. (1986). Becoming critical: Education, knowledge and action research. Philadelphia: Falmer Press.

Cherubini, L. (2009). Reconciling the tensions of new teachers' socialisation into school culture: A review of the research. Issues in Educational Research, 19(2), 83-99.

Cooper, J. M., \& Alvarado, A. (2006). Preparation, recruitment, and retention of teachers. Educational Policy Series. Paris: The International academy of Education.

Darling-Hammond, L. (1997). Restructuring schools for student success. In P. Brown, A. H. Halsey, H. Lauder, \& A. S. Wells (Eds), Education: Culture, economy, and society (pp. 332-337). Oxford, UK: Oxford University Press.

Day, Ch., \& Gu, Q. (2011). The New Lives of Teachers. London: Routledge.

Danziger, K. (1971). Socialization. Baltimore: Penguin Books.

Darling-Hammond, L. (2003). Keeping good teachers: Why it matters, what leaders can do. Educational Leadership, 60(8), 6-13.

Dinham, S., \& Scott, C. (1998). An international comparative study of teacher satisfaction, motivation, and health: Australia, England, and New Zealand. Paper presented at the AERA, San Diego, CA.

Doyle, W. (1979). Classroom effects. Theory Into Practice, 18(3), 138-144.

Eraut, M. (2002). Menus for Choosy Diners. Teachers and Teaching: theory and practice, 8(3/4), 371-378.

Fwu, B., \& Wang, H. (2002). The social status of teachers in Taiwan. Comparative Education, 38(2), 211-224.

Havlík, R. (2003). Postoje mladých učitelů k vlastní přípravě. In Sociální a kulturní souvislosti výchovy. Sborník z 11. celostátní konference ČAPV (pp. 1-6) [CD-ROM]. Brno: Paido.

Hennig, C., \& Keller, G. (1996). Antistresový program pro učitele. Praha: Portál.

Huberman, M., Grounauer, M. M., \& Marti, J. (1993). The Lives of Teachers. London: Cassell, New York: Teachers' College Press.

Humphreys, T. (1993). A different kind of teacher. New York: Cassell.

Ingersoll, R. (2003). Is there really a teacher shortage? (A research report cosponsored by the Center for the Study of Teaching and Policy and the Consortium for Policy Work in Education; Document R-03-04). Seattle: Center for the Study of Teaching and Policy. 
Janík, T., et al. (2010). Kurikulární reforma na gymnáziích. Výsledky dotazníkového šetření. Praha: VúP.

Keller-Schneider, M., \& Hericks, U. (2011). Forschungen zum Berufseinstieg. Übergang von der Ausbildung in den Beruf. In E. Terhart, H. Bennewitz, \& M. Rothland (Eds.), Handbuch der Forschung zum Lehrerberuf (pp. 296-313). Münster/New York/München/Berlin: Waxmann.

Lacey, C. (1977). The socialization of teachers. London: Methuen.

Little, J. W. (1990). Teachers as Colleagues. In A. Lieberman (Ed.), Schools as Collaborative Cultures: Creating the Future Now (pp. 165-189). New York/Philadelphia London: The Falmer Press.

Little, J. W., \& McLaughlin, M. W. (Eds.). (1993). Teachers' Work. Individuals, Colleagues and Contexts. New York/London: Teachers College, Columbia University.

Lortie, D. (1975). Schoolteacher: A Sociological Study. Chicago: University of Chicago Press. Mareš, J. (2003). Zamyšlení nad pojmem klima školy. In M. Chráska, D. Tomanová, \& D. Holoušová (Eds.), Klima současné české školy. Sborník přispěvkủ z 11. konference ČPdS (pp. 32-42). Brno: Konvoj.

Merton, R. (Ed.). (1968). Social theory and social structure. New York: New York Free Press.

Olesen, V., \& Whittaker, E. W. (1970). Critical notes on sociological studies of professional socialization. In J. A. Jackson (Ed.), Professions and professionalization (pp. 179-221). London: Cambridge University Press.

Ouyang, M. \& \& Paprock, K. (2006). Teacher job satisfaction and retention: A comparison study between the US and China. Paper presented at the Academy of Human Resource Development international conference, Columbus, $\mathrm{OH}$.

Park, R. E. (1939). Symbiosis and socialization: A frame of reference for the study of society. The American Journal of Sociology, 45(1), 1-25.

Pařizek, V. (1994). Obecná pedagogika. Praha: Pedagogická fakulta UK.

Píšová, M. (1999). Novice Teacher. Pardubice: Sci. Pap. University of Pardubice, Series C, Supplement 1.

Píšová, M. (2005). Klinický rok: procesy profesního rozvoje studentů učitelství a jejich podpora. Pardubice: Univerzita Pardubice, Fakulta humanitních studií.

Píšová, M., \& Duschinská, K. et al. (2011). Mentoring v učitelství. Praha: Pedagogická fakulta UK.

Pol, M., \& Rabušicová, M. (1997). Učitelé a rozhodovací procesy ve škole. Pedagogická orientace, 7(4), 95-100.

Pol, M., \& Lazarová, B. (1999). Spolupráce učitelů - podmínka rozvoje školy. Praha: Strom.

Pol, M., Hloušková, L., Lazarová, B., Novotný, P., \& Sedláček, M. (2013). Když se školy učí. Brno: Masarykova univerzita.

Průcha, J. (2002). Učitel. Praha: Portál.

Putz, B. (1992). Helping beginning teachers succeed. SSTA Research Centre Report No. 92-13.

Rhodes, C., Nevill, A., \& Allen, J. (2004). Valuing and supporting teachers: A survey of teacher satisfaction, dissatisfaction, morale and retention in an English local education authority, Research in Education, 71, 67-80.

Rippon, J. H., \& Martin, M. (2006). What makes a good induction supporter? Teaching and Teacher Education, 22(1), 84-99.

Sachs, J. (1999). Teacher Professional Identity: competing discourses, competing outcomes, Paper Presented at AARE Conference Melbourne. Available at: http://www.aare.edu.au 199pap/sac99611.htm.

Scherff, L. (2008) Disavowed: The stories of two novice teachers. Teaching and Teacher Education, 24(5), 1317-1332.

Staton, A. Q., \& Hunt, S. L. (1992). Teacher socialization: Review and conceptualization. Communication Education, 41(2), 109-137.

Šimoník, O. (1995). Začínající učitel. Brno: Masarykova univerzita.

Štech, S. (2007). Profesionalita učitele v neo-liberální době, Pedagogika, 57(4), 326-337.

Tolley, H., Biddulph, M., \& Fisher, T. (1996). The Professional Development Management File. Cambridge: Chris Kingston Publishing. 
80 Urbánek, P. (2001). Postoje budoucích učitelů k vlastní profesi. In Nové možnosti vzdělávání a pedagogický výzkum. Sborník z IX. konference ČAPV (pp. 130-134). Ostrava: PdF OU.

Veenman, S. (1984). Perceived problems of beginning teachers. Review of Educational Research, 54(2), 143-178.

Waller, W. (1932). The sociology of teaching. New York: John Wiley.

Wang, J., Odell, S. J., \& Schwille, S. A. (2008). Effects of teacher induction on beginning teachers' teaching: A critical review of the literature. Journal of Teacher Education, 59(2), 132-152.

Weidman, J. C., Twale, D. J., \& Stein, E. L. (2001). Socialization of graduate and professional students in higher education: a perilous passage. ASHE-ERIC Higher Education Report 28(3). Washington: Association for the Study of Higher Education.

Weiss, E. M. (1999). Perceived workplace conditions and first year teachers' morale, career choice commitment, and planned retention: A secondary analysis. Teaching and Teacher Education, 15(8), 861-887.

West-Burnham, J. (1990). Human resource management in schools. In B. Davies et al. (Eds.), Educational management for the 1990s (p. 24-38). Harlow: Longman.

Zeichner, K., \& Gore, J. (1990). Teacher socialisation. In R. Houston (Ed.), Handbook of research on teacher education (pp. 329-348). New York, London: Macmillan.

Michaela Píšová Institute for Research in School Education Faculty of Education Masaryk University Pořičí 31, 60300 Brno Czech Republic pisova@ped.muni.cz 